\title{
Coherence of Historical Genre for Young People (between Fact and Fiction)
}

\section{[Súvislosti historického žánru pre mládež (medzi faktom a fikciou)]}

\author{
Eva Vitezova
}

\section{DOI: 10.18355/XL.2015.08.03.49-56}

Anotácia

Štúdia sa zaoberá špecifickost’ou historickej prózy, ktorým je oscilovanie medzi faktom a fikciou. Historická próza v pravom zmysle slova je literárne podanie, ktorého dej sa odohráva $\mathrm{v}$ minulosti tak vzdialenej, že o nej nemáme vedomie zakladajúce sa na vlastnej pamäti alebo na správach starších súčasníkov. Tvorba textov v historickom žánri je pohybom od histórie k fikcii. Prostredníctvom literárnej fikcie autorský subjekt realitu neopisuje, nereprodukuje, ale nanovo ju tvorí. V štúdii ponúkame potenciálnu typológiu historickej prózy (pre mládež): historická povest', historická próza zachytávajúca kl'účové momenty slovenských národných dejín, dobrodružno-historický román, životopisný román, literatúra faktu.

Kl'účové slová

fakt, fikcia, povest', historická próza, dobrodružno-historický román, životopisný román, literatúra faktu

\section{Fakt a fikcia v historickom žánri}

Prostredníctvom vzájomných vzt'ahov medzi faktom a fikciou možno pochopit' a interpretovat' tak vývin literárnych druhov a literárnych smerov, ale i charakter a bytie literárnych žánrov. Tvorca literatúry fakt nepreberá v nezmenenej podobe, ale hl'adá si priestor pre osobnú realizáciu v medzerách či medzipriestoroch medzi faktami, hladá fakt ako vnútornú rozpornost' vo veciach, ako udalost' ponúkajúcu problém na riešenie. Historické fakty sú základným predmetom záujmu historiografie a týmto pomenovaním v nej označujeme minulé prejavy existencie a činnosti človeka a celej l'udskej spoločnosti. Tieto fakty svojím spôsobom predstavujú a odrážajú historické pramene a ich štúdiom historická veda smeruje $\mathrm{k}$ poznatkom o minulej objektívnej realite, ktoré sa $\mathrm{v}$ tomto vednom odbore označujú ako historiografické fakty. Tvorivá činnost' autora historického prozaického diela (pre mládež) stojí na jednej strane v blízkosti rozhl'adeného historika, na druhej strane sú pre ňu príznačné špecifické zákonitosti tvorby literárneho umeleckého „výtvoru“, artefaktu. Dôraz tu stojí na slove „výtvor“, slove, ktoré v značnej miere korešponduje so slovami výmysel, fikcia, domýšl’anie, teda s tým, čo sa bezprostredne dotýka modelovania sveta a života v literárnom diele. René Bílik (2008: 19) tvrdí, že ,...z hl'adiska vzt'ahu historiografie a umeleckej literatúry je tvorba textov v historickom žánri pohybom od histórie $\mathrm{k}$ fikcii“. V historickej próze dokumentárna funkcia literárneho diela vystupuje $\mathrm{v}$ podobe preferencie historického faktu, ktorý sa vyznačuje vymedzeným štatútom objektívne a preukazne daného, zaznamenaného, overeného, potvrdeného. Pritom „domýšl'anie a vymýšl’anie detailov v historickej próze, ktoré je z prirodzených dôvodov nevyhnutné, býva spravidla aspoň v koncepčnej zhode s faktickými danost’ami rozprávanej histórie. Princípy fabuly, sujetu, tvaru ostávajú však na prvom pláne. Fakt ostáva faktom, ale ako prvok fabuly, sujetu, tvaru“ (Miko, 1991: 149).

Slovo fikcia vo filozofickom chápaní znamená určitý predpoklad, ktorý môže slúžit' ako metodický prostriedok alebo hypotéza v priebehu poznávacieho procesu. Z literárneho hl'adiska fikcia súvisí s otázkou tzv. pravdivosti literárneho 
diela, v najkrajnejšom prípade ide teda o akúkol’vek nezhodu so skutočnost'ou. Fikcia označuje celý významový komplex literárneho diela odlišný od empirickej mimoliterárnej skutočnosti, čím sa potom rozumie v súlade s etymológiou výrazu to, čo pomenúvame aj v literatúre frekventovaným slovom - „výtvor“ (Vlasin, 1977: 112). Modelovanie obrazu sveta $\mathrm{v}$ texte sa $\mathrm{v}$ literatúre stáva výsostne individuálnym tvorivým aktom a výsledok tejto tvorby sa prezentuje ako literárny artefakt. Literárna fikcia je charakteristická vlastnost' sveta modelovaného v literárnom diele spočívajúca v tom, že tento je vytvorený „,výmyslom“ autora. Niektoré prvky literárnej fikcie (napr. spoločenské reálie, historické udalosti, topografické dominanty atd'.) môžu vykazovat' niektoré zhodné črty s určitými úkazmi skutočnosti, iné (literárne postavy) môžu zodpovedat' potenciálnym predstavitel'om zastupujúcim určité odvetvia l'udskej činnosti alebo spoločenské zoskupenia, s ktorými sa čitatel' stretáva v každodennom živote, a d’alšie (napr. zauzlenie akcie) majú výslovne kompozičný charakter. No nielen jednotlivé prvky sveta zobrazovaného v diele, ale aj literárne dielo ako celok sa svojou vlastnou umeleckou štruktúrou vzt'ahuje na l'udskú skúsenost' a skutočnost', na osobné zážitky, spoločenské udalosti, historické procesy. S odkazom na tento moment, tzn. na prítomnost' a dôležitost' fiktívnej vrstvy popri vrstve historickej fakticity v historickom románe, môžeme historický žáner definovat' ako žáner určený predovšetkým tematickým hl’adiskom, tzn. zameraním na deje minulých čias, a materiálom, ktorého základ tvoria historické fakty a reálie, ktoré majú evokovat' obraz daného historického obdobia, a to aj prostredníctvom fiktívneho príbehu a fiktívnych postáv. Historický žáner teda hodnotíme podl'a historickej pravdivosti, čím však nemyslíme len „pravdivost"“ fabuly, ale aj vystihnutie dobového spôsobu života a myslenia.

Slovenská historická próza (napr. diela J. M. Hurbana, J. Kalinčiaka, L. N. Jégého, M. Kukučína, T. Vansovej) si v čítaní detí a mládeže nenašla ani v jednom prípade také miesto, ktoré by znamenalo presun niektorého diela do oblasti neintencionálnej literatúry pre deti a mládež. Isté ambície možno pripísat' Jégého románu Adam Šangala. Pokial' ide o potenciálnu typológiu súčasnej historickej prózy pre mládež po roku 1945, prvým okruhom je historická povest', druhým historická próza (najčastejšie román) zachytávajúca klúčové momenty slovenských národných dejín, tretím dobrodružno-historický román, štvrtým životopisný román a ostatným literatúra faktu.

\section{Historická povest'}

„Možno to nie je celkom pravda, ale ani trošku to nie je nepravda.“ Týmito slovami končí Jozef Melicher jednu z povestí zo svojej knihy Od Zobora po Sitno. Vystihuje nimi azda najpresnejšie zmysel a obsah pojmu povest' a zároveň naznačuje to, ako treba povesti čítat' a čo $v$ nich treba hl'adat'. Povest' je teda $\mathrm{z}$ jedného uhla pohl'adu skutočnou príhodou, ako ju preživa a interpretuje slovesná folklórna tradícia, na druhej strane je vyjadrením ,pravdy“ stojacej d’aleko od skutočnosti, čo je zasa výsadou slovesného umenia vo všeobecnosti. Dejinná existencia (reálne) v povesti nesvedčí o historickosti námetu, je iba vonkajšková, formálna. Nejde tu o poznanie, ale „o fikciu, ... o pridávanie poetického čara historickým postavám. Konkrétne dejinné postavy sú iba akoby náhodnými nositel'mi povest’ovej štruktúry“ (Klátik, 1971: 63). Fantastika je - podl’a J. Heldovej (1985: 12) - „,neskutočno v estetickom zmysle, teda to, čo si možno predstavit' a čo nie je viditel'né zrakom všetkých, čo neexistuje pre všetkých, ale čo je vytvorené predstavivost'ou, obrazotvornost'ou ducha“. Fiktívne v historickej povesti je súčast'ou reálneho, fantastické je súčast'ou deja. Miera vzájomnej súvzt'ažnosti reálneho, fiktívneho a fantastického je aj estetickou mierou jej pôsobenia na príjemcu. 
Historické povesti súvisia s významnými historickými udalost’ami a postavami a vytvárajú dva vel'ké celky: prvý tvoria povesti bezprostredne spojené so slovenskými dejinami, druhý zasa povesti - rozprávania o starých časoch, späté s historicky identifikovatel'ným spoločenským a kultúrnym prostredím. Pre prvý celok sú príznačné tieto historické tematické okruhy: obdobie Vel'komoravskej ríše, vpád Tatárov na naše územie, obdobie vlády krála Mateja, obdobie tureckých vojen a nájazdov, prítomnost' husitských vojsk na Slovensku, povesti so zbojníckymi námetmi, tematika revolučných rokov 1848 - 1849 a Slovenského národného povstania. Druhý povest'ový celok vytvárajú viaceré námetové okruhy povestí, napr. o l'udovom pôvode mien l'udí, názvov a pomenovaní častí chotárov, hôr, vrchov, riek, osád, skál, d’alej o hradoch a zámkoch, o zaniknutých dedinách, jazerách, o pokladoch, o zakliatych rytieroch atd'. Tieto povesti sa od predchádzajúcich, vzt'ahujúcich sa bezprostredne na slovenské národné dejiny, líšia aj tým, že sa vyskytujú aj $\mathrm{v}$ iných národných folklórnych tradíciách a fondoch. Ušlachtilý zbojník Robin Hood je vo svojich životných úsiliach predchodcom Jánošíka alebo Ondráša či Juráša, spiace vojsko nájdeme rovnako pod naším Sitnom, ale aj v jaskyni pod nemeckou, lužickou, pol'skou alebo českou horou, bielych panien chodí nekonečné množstvo po všetkých európskych hradoch a zámkoch atd'. Tento povest'ový celok sa v jestvujúcej slovenskej odbornej literatúre zastrešuje pomenovaním „miestne“ povesti. Autormi (spracovatel'mi) historických povestí v slovenskom kontexte sú napr. Milan Ferko, Jozef Melicher, Ján Domasta, Jozef Horák, Anton Habovštiak, v súčasnosti Zuzana Zemaníková, Jozef Tatár, Peter Urban a iní.

\section{Historická próza}

Ako príklad historickej prózy nám poslúži prvá umelecká historická próza vo vývine slovenskej literatúry pre deti a mládež, historická novela Jozefa Cígera Hronského Sokoliar Tomáš (1932). Hronského dielo vychádza v čase, ked'sa historická próza síce začínala vo vel'kom pestovat', no jej tvorba „sa stala doménou netalentovaných autorov, ktorí detskú literatúru stále chápali len ako odnož didaktického pôsobenia...“ a ktorej základnými črtami „,bola deskriptívna faktografia, dobrodružná osnova príbehu, neraz úplne zatláčajúca historickost' do pozície tematickej kulisy, literátske rozpracovanie povest’ových motívov, resp. motívov imitujúcich povest'ový materiál, literárny sujet, vyúst’ujúci do moralizátorskej pointy, schematická profilácia postáv a štylistický verbalizmus“ (Sliacky, 1990: 197).

Vonkajším podnetom pre napísanie tohto diela je štúdia Jozefa Martinku Sokoliarstvo na Slovensku, uverejnená v Slovenských pohl'adoch v roku 1929. Ďalej je tu spomenutá časová zakotvenost' údajom „pred šest'sto rokmi“. Hronský teda čerpal historický faktografický materiál $\mathrm{z}$ odborného prameňa a jeho značnú čast' transponoval do informatívno-vzdelávacej polohy. Tento zámer autora je potom rozšírený predovšetkým o živú panorámu stredovekého života na hradoch a zámkoch a v príbytkoch poddaných. Príbeh o chlapcovi - sokoliarovi Tomášovi, ktorý feudálnemu pánovi Balážovi zmárnil besného loveckého psa a ktorý pred pomstou tohto krutého pána uteká do hlbokých hôr, kde sa dostáva do ochranných rúk starého Varčiaka, múdreho a dobrého človeka, sa postupne pretavuje z polohy sociálneho konfliktu do polohy morálneho konfliktu. Morálne kvality tohto človeka sa prejavujú v sprievodných krízových situáciách, najmä však v jeho vzt’ahu k d’alšiemu sokoliarovi - zločinnému Il’okovi. Celý príbeh končí zmierlivo v duchu filozofie odporovania zlu nenásilím: sokoliar Tomáš odchádza s mladým pánom Oguzom na hrad jeho otca, pána župana Donča. Základným zmyslom Sokoliara Tomáša „nie je hl'adat' v minulosti analógie bytostných problémov súčasného človeka a spoločnosti. Historickost' nie je tu iba zvláštnou podobou a konkretizáciou všeobecne l'udského a nadčasového. Je východiskom i ciel'om zobrazenia“" (Poliak, 1970: 119). 
V historickej novele J. C. Hronského sa stretávame aj s jedným zaujímavým javom, a to s tým faktom, že v historickej próze určenej pre mládež ide väčšinou o dospelého, nie detského hlavného hrdinu. Z nadpisu prózy je zrejmé, že protagonistom Hronského prózy je sokoliar Tomáš. Skutočným hrdinom je však Varčiak - je nositel'om kladnej myšlienky novely a jedným zo zjednocujúcich prvkov epického obrazu. Druhým je rozprávač, ktorý stojí nad hlavnou postavou a má nad všetkým náležitý dohl'ad a rozhl’ad. V literatúre pre dospelých $\mathrm{v}$ rozpätí rokov aktívnej umeleckej činnosti J. C. Hronského pretlačili sa do popredia dva najproduktívnejšie typy historického žánru: dobrodružno-morálny (Hrušovský, Nižnánsky) a baladický (Hronský, Gráf, Rysulaa), spätý s prejavmi literárneho naturizmu. Ich spoločnou ideovou platformou sa stala koncepcia národného historizmu. V literatúre pre deti a mládež medzivojnového obdobia podobnú typológiu robit' nemožno, pretože absentovalo širšie spektrum titulov. V neskoršom období sú autormi historických románov pre mládež napr. Jozef Horák alebo Zuzana Kuglerová.

\section{Dobrodružno-historický román}

Jana Nemcová, ktorá sa zaoberala problematikou dobrodružno-historického románu, charakterizovala túto žánrovú formu historickej prózy takto: „Ak je východiskovým motívom dobrodružná fantázia a ciel'ovým hodnotové posolstvo, ak je primárna zábavná funkcia, ale sleduje sa aj aspekt poznania, ide o typ historickodobrodružný. Tento žáner nelimituje rozlet fantázie a nepočíta s odpoved’ou na zásadné - hoci často znepokojujúce - l'udské otázky. Ponúka exkurz do histórie s tým, že stretnutie známeho sveta so svetom minulosti je iba hrou a výsadou autorovej imaginácie a fabulácie“ (Nemcova, 1996: 190). Výstavbovým prostriedkom sú súboje, tajné únosy, skryte vypočuté úklady a prekvapujúce udalosti, rozprávkoví hrdinovia.

Reprezentatívnym dielom tohto druhu je Dumasov román Traja mušketieri a dve jeho pokračovania (odohrávajúce sa po dvadsiatich a potom ešte po desiatich rokoch). Román zaujme rovnako kresbou francúzskej dvorskej a šlachtickej spoločnosti v 17. storočí, ako aj hlavnou postavou mladého gaskoňského šl'achtica d'Artagnana, prvého pravého „supermana“" svojej doby, a jeho druhov: uhladeného, rozumného a rozvážneho Athosa, dobráckeho, obetavého a silného Porthosa a jemného vnímavého Aramisa. Všetci štyria sú l'udsky prít'ažliví, vyznačujú sa bystrost'ou, vel'korysost'ou, čo už sú vlastnosti vel'mi blízke poetike l'udovej rozprávky, najmä ak položíme dôraz na ich morálku vít’azstva dobra nad zlom, na prekonávanie všetkých prekážok, čo im stoja v ceste za ušl'achtilým ciel’om.

V slovenskom literárnom kontexte sa povahou uchopenia historickej látky približujú Dumasovi niektoré románové diela J. Nižnánskeho napísané v tridsiatych rokoch dvadsiateho storočia. Aj ony, podobne ako Traja mušketieri, vd'ačia za svoju čitatel'skú popularitu viac mládeži než dospelým, ktorým boli pôvodne určené. „Zdrojom Nižnánskeho dodnes neslabnúcej obl'úbenosti je schopnost' l'ahko odvíjat' vzrušujúce romantické deje $\mathrm{v}$ štýle rozprávky pre naivné dospelé deti, dychtiace po úniku z ubíjajúcej každodennosti do neskutočnej ríše nepremožitel’ných hrdinov a nežných princezien," konštatuje sa o Nižnánskom a jeho historicko-dobrodružných románoch v Slovníku slovenských spisovatel'ov pre deti a mládež (Sliacky, 1970: 169). Tieto príbehy napriek dobovým reláciám a letopočtom nenavodzujú dobovú atmosféru, ba ani vedomie presne lokalizovanej historickej epochy. V podstate rozprávkoví sú i hrdinovia, vymodelovaní bez akýchkol'vek odtieňov: hrdina je rytier, zloduch - stelesnený diabol, poddaní síce trpia, no láska hory prenáša a dobro vít’azí nad zlom. V poslednom čase sa tejto forme historického žánru (pre mládež) pri značnom zvýšení estetických kritérí na povahu faktu a fikcie i výsledný umelecký tvar venoval P. Glocko. Ďalšími autormi sú napr. Zuzka Zguriška, Milan Ferko, Mária Ďríčková, Alta Vášová a Zuzana Kozičová. 


\section{Životopisný román}

Teoretickými otázkami životopisného románu a životopisnej literatúry so zretel'mi na literatúru pre mládež sa zaoberal Vladimír Petrík v štúdii K vývinovým formám životopisnej prózy. Konštatoval, že životopisná próza podlieha všeobecným zákonitostiam historického žánru, pričom sa sústred'uje na problém vzt'ahu medzi historickou osobnost'ou a masami (l'udom), vzt'ahu medzi historickou a umeleckou pravdou, problém ahistorizmu, aktualizácie atd’. Základné protirečenie, na ktorom je vybudovaná životopisná umelecká literatúra, podl’a jeho názoru tvorí napätie medzi faktom a predstavou o tomto fakte, t.j. fikciou. „Tvorca sa prikláňa raz k vernému, historicky adekvátnemu interpretovaniu faktov, inokedy vkladá do objektu svojho výskumu predovšetkým vlastný výklad, usiluje sa o svojské, osobitné poňatie historickej osobnosti, často bez ohl'adu na reálne fakty, ba neraz proti nim“ (Petrik, 1963: 52).

Novodobý životopisný román je nepriamym dedičom hrdinského eposu, počnúc od babylónsko-asýrskeho eposu o Gilgamešovi cez tzv. homérske básne a antickú historickú prózu. O tom, či má bližšie, resp. či patrí do oblasti historickej umeleckej prózy alebo do oblasti literatúry faktu, rozhoduje na prvom mieste autorský zámer, resp. autorská stratégia, pre ktorú je príznačné to, či sa rozhodne položit' dôraz na zobrazovanie subjektu životopisného diela, tzn. na jeho životopisné vývinové zretele (napr. na určitý výsek z jeho života; ako ret’az činov, v ktorých je isté napätie a dynamika) alebo rozvíja objekt činnosti životopisného protagonistu, čiže to, čo robí, o čo sa usiluje, tú oblast' jeho pôsobenia, o ktorej rozvoj a rast sa sám významnou mierou pričinil. Tejto problematike sa okrem V. Petríka venuje aj Z. Klátik v práci Slovo, klúč k detstvu. Klátik navyše k svojmu výkladu pripája aj schému typológie životopisu, z ktorej možno vyčítat', že pre literárny životopis, ktorý z hl'adiska žánrov zastupuje predovšetkým román a novela, je príznakové epické rozprávanie, kronikárska kompozícia, fabula a psychologický alebo antropologický aspekt (Klatik, 1975: 186).

Pokial' ide o vlastné proporcie reálneho a fiktívneho $\mathrm{v}$ životopisnej forme historického žánru za dôležité treba pokladat' aj zistenia M. Žilkovej (1976: 77 - 94) o stabilných a pohyblivých faktoroch životopisu. Podl'a nej životopis je vel'mi labilný literárny útvar, kde možno mnohé fakty pridávat' a uberat' bez toho, aby sa zmenil jeho charakter a podstata: autor si z jeho života vyberá také fakty, ktorými podopiera svoje tvrdenie, svoj názor, postoj. Ak ich nenachádza vo vlastnej subjektovej biografii, priberá si na pomoc fikciu, tzn. predstavu o potenciálnych faktoch ako jeden z najdôležitejších pohyblivých faktorov.

V slovenskej literatúre pre deti a mládež za modelové životopisné romány možno pokladat' diela Luda Zúbka, Jozefa Horáka, Zlaty Dônčovej, Eleny Chmelovej a Nory Baráthovej.

\section{Literatúra faktu}

„Vedomie súčasnej mladej generácie je plné bielych miest historického mlčania. Nevstrebalo do seba pekne po poriadku ani individuálnu rodinnú minulost', ani sociálnu minulost'“" konštatuje vo svojej knihe Étos a dejiny Éva Ancselová (1984: 133). Na inom mieste túto myšlienku rozvíja: „Preto je možné, že táto nová generácia, vyrastajúca bez otrasov a vojny, ktorá by si mohla už ,len' osvojovat' minulost' svojej rodiny a vlasti, je neistejšia a labilnejšia ako tí, čo vedia, ako a prečo s nimi osud zmietal hore - dolu v historickom procese. Poznat' odpoved' na ,prečo' ešte neznamená získat' postačujúcu interpretáciu. Znamená len znalost’ faktov“ (1984: 131).

Medzi čitatel'mi historickej prózy je vel'mi vel'a tých, ktorí sa na ňu nedívajú ako na umelecký fenomén, ale ako na zdroj informácií, nenásilného poučenia o minulosti. Historická literatúra faktu si tiež nárokuje na umelecké ambície. A tak, ako na to poukazuje aj B. Dokoupil (1988: 78), stávame sa svedkami procesov, pri ktorých 
ani tak nedochádza $\mathrm{k}$ vytláčaniu jedného typu typom druhým, ako skôr k vzájomnému prelínaniu (alebo miešaniu) beletristických postupov.

Literatúre faktu patrí plná kompetencia odpovedat' nielen na otázku ,ako“, ale i na otázku ,prečo“, v rámci ktorej v popredí stojí faktografia, hl'adanie súvislostí medzi javmi minulosti, vášeň z objavovania alebo dobrodružstvo poznávania, predsa len táto del'ba polôh a prístupov je tu evidentná. Pre krásnu literatúru, do sféry ktorej patrí aj historická próza, fakty nie sú ciel’om, ale prostriedkom $\mathrm{k}$ hlbšiemu pochopeniu človeka. Pri literatúre faktu poznávací a informačný úspech spočíva v autorovej schopnosti objavit' zaujímavé fakty a nájst' vhodný spôsob ich zret'azenia a prezentácie. Hranica medzi obidvoma týmito literárnymi typmi za istých okolností, napr. pri biograficko-historickej tematizácii, nie je taká ostrá, aby nemohlo dôjst' k vzájomným posunom, k vzájomnému ovplyvňovaniu, k vzájomnému preskupovaniu niektorých funkčných prvkov i postupov. Autormi kníh literatúry faktu s historickou tematikou v slovenskom kontexte sú napr. Vojtech Zamarovský, Ludo Zúbek, Ján Juríček, Matúš Kučera, Dušan Kováč, Ján Hučko.

\section{Záver}

Špecifickost'ou historickej prózy je prítomnost' dvoch dôležitých faktorov, súvisiacich $\mathrm{s}$ vnímaním a pôsobením literárneho diela. Je to oscilovanie medzi faktom a fikciou, ktoré tvorí základný výstavbový princíp z hl’adiska tematizácie ,životného sveta“ v literárnom diele. Tomuto zodpovedá aj samotná povaha literárneho diela, ktorá nezohl'adňuje len nadväznost' na literárnu tradíciu, ale vel'mi vážne reaguje aj na súčasnú literárnu situáciu $\mathrm{v}$ tomto smere, a to - v našom prípade - v špecifickej oblasti literatúry pre deti a mládež. V slovenských dielach s historickou tematikou určených pre mládež prevláda viac-menej priame pôsobenie, založené na priamej výpovednej hodnote historických faktov, ale aj na literárnej fikcii, orientujúcej sa jednoznačne na pravdivé vykreslenie historickej atmosféry doby, prostredia, l’udí a ich vzájomných vzt'ahov, udalostí a pod. Scenéria historického času, priestoru a ducha je do istej miery individualizovaná záberom a zámerom autora zaujat' stanovisko $\mathrm{k}$ historickej realite a k rešpektovaniu toho stanoviska doviest' aj čitatel'a.

\section{References}

ANCSELOVA, E. 1984. Etos a dejiny. Bratislava: Nakladatelstvo Pravda.

ANTON, T. M. 2012. Fiction and history on the prime literary attempts of the Icelandic letters. The representation from the past. In: Revista de Literatura Medieval, Vol. 24, pp. 141-153. ISSN 1130-3611

BENES, B. 1990. Ceska lidova slovesnost. Praha: Odeon. ISBN 80-207-0181-8

BILIK, R. 1992. Funkcia historickeho faktu v texte historickeho zanru. In: Slovenska literatura, vol. 39, n. 6, pp. 461 - 470. ISSN 0037-6973

BILIK, R. 2008. Historicky zaner v slovenskej proze. Bratislava: Kalligram a Ustav slovenskej literatury SAV. ISBN 978-80-8101-137-5

CULLER, J. 2005. Studie k teorii fikce. Praha - Brno: UCL AV CR. ISBN 80-85778-

46-7

CORPORAAL, M. 2010. From golden hills to sycamore trees: Pastoral homelands and ethnic identity in Irish immigrant fiction, 1860-75. In: Irish Studies Review, Vol. 18, Issue 3, pp. 331-346. ISSN 0967-0882

DOKOUPIL, B. 1988. Cas cloveka, cas dejin. Poznamky k vyvoji ceske historicke prozy 1966 - 1986. Praha: Ceskoslovensky spisovatel.

ECO, U. 2013. Zpoved mladeho romanopisce. Praha: Argo. ISBN: 978-80-257-10289 
GENETT, G. 2007. Fikce a vypraveni. Praha - Brno: UCL AV CR. ISBN 978-8085778-00-7

HELDOVA, J. 1985. V risi obrazotvornosti. Praha: Albatros.

HRABAK, J. 1973. Poetika. Praha: Ceskoslovensky spisovatel.

HRONSKY, J. C. 1969. Sokoliar Tomas. Bratislava: Mlade leta.

CHAMBERS, S. 2010. When the drumbeat changes. In: Rethinking History, Vol. 14, Issue 1, pp. 151-158. ISSN 1364-2529

JAKUBOVSKA, V. 2014 Multicultural communication and its specifics in the literature. In: XLinguae : European Scientific Language Journal, Vol. 7, Issue. 2, pp. 45-60. ISSN 1337-8384

KLATIK, Z. 1971. Krajina plna detstva. Hronského tvorba pre mladez. Bratislava: Mlade leta.

KLATIK, Z. 1975. Slovo, kluc k detstvu. Dielo, druh, kontext v tvorbe pre mládež. Bratislava: Mladé letá

KUBICEK, T. 2001. Semiotika zanru historicke fikce. In: Ceska literatura, vol. 59, n. 5, pp. 655 - 677. ISSN 0009-0468

LESCAK, M. - SIROVATKA, O. 1982. Folklor a folkloristika. O ludovej slovesnosti. Bratislava: Smena.

LUKACS G. 1976. Historicky roman. Bratislava: Tatran.

MELICHER, J. 1998. Od Zobora po Sitno. Historicke povesti a folklorne crty z juzneho Slovenska. Bratislava: DONY. ISBN 80-968087-1-0

MIKO, F. 1991. Fakt v literature - literatura faktu. In: Zanrove aspekty textu literatury pre deti a mladez. Bratislava: Mlade leta, pp. 146 -159.ISBN 80-06-00216-9 MOCNA, D. - PETERKA, J. a kol. 2004. Encyklopedie literarnich zanru. Praha Litomyšl: Paseka. ISBN 80-7185-669-X

NEMCOVA, J. 1996. Putovanie do hlbín času... a historicko-dobrodruzneho zanru. In: Zanrove hodnoty literatury pre deti a mladez III. Nitra: VSPg, pp. 177 - 191. ISBN 80-8050-072-X

PETRIK, V. 1963. K vyvinovym formam zivotopisnej prozy. In: O umelecko-naucnej literature. Bratislava: Mlade leta, pp. $51-61$.

POLIAK, J. 1970. Vzdelavaci aspekt v historickej proze (Jozef Ciger Hronsky:

Sokoliar Tomas). In: Dieta, literatura, autor. Interpretacie. Bratislava: Mlade leta, pp. $117-128$.

PREDA, D. 2014. Compassion as remedy against violence and fanaticism: Thoughts on Borges and $\mathrm{Oz}$. In: Revista Transilvania, Issue 7, 2014, pp. 83-85. ISSN 02550539 SLIACKY, O. 1990. Dejiny slovenskej literatury pre deti a mladez do roku 1945. Bratislava: Mlade leta. ISBN 80-06-00150-2

SLIACKY, O. a kol. 1970. Slovnik slovenskych spisovatelov pre deti a mladez. Bratislava: Mlade leta.

STEVCEK, J. 1989. Dejiny slovenskeho romanu. Bratislava: Tatran. ISBN 80-2220036-0

VITEZOVA, E. 2005. Vyznamove a zanrove charakteristiky povesti. Bratislava: OG - Polana. ISBN 80-89192-25-4

VLASIN, S. a kol. 1977. Slovnik literarni teorie. Praha: Ceskoslovensky spisovatel. WALDNEROVA, J. 2013. Transworld identities and contemporary literature. In: XLinguae: European Scientific Language Journal, Vol. 6, Issue 3, pp 2-10. ISSN 1337-8384

ZAPLETAL, Z. 1986. K promenam a tendencim zivotopisne prozy. Zlaty maj, n. 8, pp. $450-453$.

ZILKOVA, M. 1976. Zivotopis a zivotopisne fakty v literarnej historiografii. In: Biografistika v systeme literarneho vzdelania. Dolny Kubin - Nitra: Literarne muzeum P. O. Hviezdoslava - KLKEM, pp. 77 - 94. 
Words: 3503

Characters: 25217 (14,01 standard pages)

Prof. PaedDr. Eva Vitézová, PhD.

Department of Slovak Language and Literature

Faculty od Education, Trnava University in Trnava

Priemyselná 4

P. O. Box 9

91843 Trnava,

Slovak Republic

eva.vitezova@truni.sk 